\title{
PENGARUH STRUKTUR ASET, UKURAN PERUSAHAAN, PROFITABILITAS TERHADAP NILAI PERUSAHAAN
}

\author{
The Influence Of Asset Structure, Corporate Size, Profitability Of Corporate Value
}

\author{
Fides Alfida Pamungkas ${ }^{1}$ \\ Anita Wijayanti, SE,MM,Ak, $\mathrm{CA}^{2}$ \\ Rosa Nikmatul Fajri, SE,M,Acc ${ }^{3}$ \\ Accounting, Faculty of Ecomics, Islamic Batik University of Surakarta ${ }^{1}$ \\ fidesalfida@gmail.com ${ }^{1}$ \\ itax_solo@yahoo.com ${ }^{2}$ \\ rosanikmatulfajri@mail.ugm.ac.id ${ }^{3}$
}

\begin{abstract}
ABSTRAK
Dunia bisnis saat ini saat ini semakin ketat persainngannya perusahaan bertahan dan berjaya hanya jika mereka bisa terus meluncurkan produk atau jasa baru. Untuk itu, setiap perusahaan harus senantiasa meningkatkan kinerjanya dalam rangka meningkatkan nilai perusahaanya. Penelitian ini bertujuan untuk menguji dan menganalisi seberapa besar pengaruh struktur aset perusahaan, dan profitabilitas terhadap nilai perusahaan. Penelitian ini menggunakan dimensi struktur aset, ukuran perusahaan dan profitabilitas sebagai variabel independen dan nilai perusahaan sebagai variabel dependen. Sampel penelitian adalah perusahaan sub sector real estate, properti, dan konstruksi bangunan yang terdftar di Bursa Efek Indonesia tahun 2015-2018 mengakuisisi 72 perusahaan. Metode pemilihan sampel menggunakan purposive sampling mengakuisisi 40 perusahaan dan sampel menjadi 89 setelah terjadi outlier. Penelitian ini menggunakan analisis regresi linier berganda dengan uji hipotesis statistik menggunakan IBM SPSS stastictik 22. Hasil penelitian ini mengungkapkan bahwa Struktur aset dan Profitabilitas berpengaruh terhadap nilai perusahaan. Sedangkan Hasil dari ukuran perusahan tidak berpengaruh pada nilai perusahaan
\end{abstract}

Kata kunci: Struktur Aset, Ukuran Perusahaan, Profitabilitas, Nilai Perusahaan.

\section{ABSTRACT}

Today's business world is getting tougher about how companies survive and prosper only if they can continue to launch new products or services. For this reason, every company must constantly improve its performance in order to increase the value of the company. This study aims to discuss and analyze the major influence of company assets, and profitability on firm value. This study uses the dimensions of asset structure, company size and profitability as independent 
variables and firm value as the dependent variable. The research sample is the real estate, property, and building construction sub-sector companies listed on the Indonesia Stock Exchange in 2015-2018 acquired 72 companies. The sample selection method uses purposive sampling to acquire 40 companies and the sample becomes 89 after an outlier occurs. This study uses multiple linear regression analysis with a statistical hypothesis test using the IBM SPSS statistical test 22. The results of this study discuss the structure of assets and profitability associated with firm value. While the results of the company's size are not determined on the company's value

Keywords: Asset Structure, Company Size, Profitability, Company Value.

\section{PENDAHULUAN}

Dunia bisnis adalah dunia yang penuh dengan ketidakpastian, namun di samping itu kegiatan bisnis selalu berkembang seiring berjalannya waktu. Banyaknya perusahaan yang ada saat ini membuat persaingan antar perusahaan semakin ketat. Brealey et.al (2007: 4) menyatakan bahwa dunia bisnis bisa sangat bersaing, dan perusahaan bertahan dan berjaya hanya jika mereka bisa terus meluncurkan produk atau jasa baru. Untuk itu, setiap perusahaan harus senantiasa meningkatkan kinerjanya dalam rangka meningkatkan nilainya.

Meningkatnya nilai perusahaan menunjukkan meningkatnya kemakmuran pemilik atau para pemegang sahamnya. Oleh karena itu, tingginya nilai perusahaan sudah pasti menjadi tujuan utama sebuah perusahaan khususnya perusahaan go public. Selain itu nilai perusahaan yang baik menunjukkan bahwa kinerja perusahaan juga baik sehinggaakan menarik investor untuk menanamkan modalnya. Harga saham dan nilai perusahaan mengikhtisarkan penilaian kolektif investor tentang seberapa baikkah keadaan suatu perusahaan, baik kinerja saat ini maupun prospek ke depannya (Brealey et.al, 2007: 46).

Sebagai investor sebelum melakukan investasi dapat melakukan analisa untuk melihat kinerja perusahaan. Analisis yang biasa dilakukan adalah analisis laporan keuangan. Salah satu cara yang digunakan dalam analisis laporan keuangan adalah dengan menggunakan rasio keuangan. Rasio keuangan yang digunakan dalam penelitian ini meliputi rasio struktur aset, ukuran perusahaan, dan profitabilitas. 
Penelitian mengenai struktur aset yang dilakukan oleh Setiadharma (2017) menunjukan bahwa Terdapat pengaruh langsun struktur aset terhadap nila perusahaan. Hasil ini tidak sejalan dengan penelitian yang dilakaukan oleh Muslichah (2017) mengatakan bahwa tidak terdapat pengaruh langsung struktur aset terhadap nilai perusahaan.

Untuk ukuran perusahaan Penelitian yang dilakukan oleh Putu Ayu (2018) mendapatkan hasil bahwa ukuran perusahaan berpengaruh positif terhadap nilai perusahaan. Sementara penelitian yang mendapatkan hasil bertentangan yaitu yang dilakukan oleh Eka (2017) menemukan hasil bahwa ukuran perusahaan tidak berpengaruh terhadap nilai perusahaan.

Dan untuk profitabilitas yang dilakukan oleh Eka indriyani (2017), yang diuji dengan menggunakan ROA mendapatkan hasil bahwa profitabilitas berpengaruh terhadap nilai perusahaan. Namun, hasil berbeda diperoleh dari penelitian yang dilakukan oleh Yastini (2015) dimana ROA tidak berpengaruh terhadap nilai perusahaan.

Berdasarkan penelitian sebelumnya yang dimana hasilnya berbeda beda. Maka dari itu dapat di simpukan bahwa peneltian sebelumnya menujukan hasil yang tidak konsisten maka dalam penelitian ini akan meneliti tentang "Pengaruh Struktur Aset, Ukuran perusahaan, Profitabilitas tehdap nilai perusahaan" .Penelitian ini bertujuan untuk mengetahui pengaruh Struktur Aset, Ukuran perusahaan, Profitabilitas tehdap nilai perusahaan. Manfaat penelitian ini dapat diajadikan bahan referensi bagi peneliti salanjutnya dimasa mendatang tentang dimensi struktur aset, ukuran perusahaan dan profitabilitas terhadap nilai perusahaan dan menambah pengetahuan bagi investor yang akan mengiveskan ke perusahan yang telah diteliti ini dan bagi perusahaan untuk menjadikan perusahaan yang sehat dengan adanya penelitian ini.

Grand theory adalah teori utama yang digunakan sebagai landasan atau dasar lahirnya teori - teori dari suatu variabel, teory yang digunakan dalam penelitian ini yaitu: 


\section{Teori Signaling}

Teori Sinyal menurut Brigham dan Houston (1999) dalam Fenandar (2012) adalah tindakan perusahaan dalam memberi sinyal kepada investor tentang bagaimana manajemen memandang perusahaan. Teori sinyal membahas bagaimana seharusnya sinyal-sinyal keberhasilan atau kegagalan manajemen (agen) disampaikan kepada pemilik (principal). Dorongan dalam memberikan sinyal timbul karena adanya informasi asimetris antara perusahaan (manajemen) dengan pihak luar, dimana investor mengetahui informasi internal perusahaan yang relatif lebih sedikit dan lebih lambat dibandingkan pihak manajemen.

Nilai perusahaan dapat ditingkatkan dengan mengurangi informasi asimetris, caranya dengan memberikan sinyal kepada pihak luar berupa informasi keuangan yang dapat dipercaya sehingga dapat mengurangi ketidakpastian mengenai prospek pertumbuhan perusahaan pada masa yang akan datang. Laporan keuangan yang baik akan meningkatkan nilai perusahaan. Pada signalling theory, manajemen berharap dapat memberikan sinyal kemakmuran kepada pemilik ataupun pemegang saham dalam menyajikan informasi keuangan. Publikasi laporan keuangan tahunan yang disajikan oleh perusahaan akan dapat memberikan sinyal pertumbuhan strutur aset, ukuran perusahaan, profitabilitas maupun perkembangan harga saham perusahaan. Informasi tersebut penting bagi investor dan pelaku bisnis karena mengandung banyak catatan, rincian dan gambaran keadaan masa lalu, saat ini, dan tentu saja masa yang akan datang untuk memperkirakan kemajuan perusahaan dan akibatnya pada perusahaan. Informasi laporan keuangan yang mencerminkan nilai perusahaan merupakan sinyal positif yang dapat mempengaruhi opini investor dan kreditor atau pihak-pihak berkepentingan lainnya. Peningkatan utang diartikan oleh pihak luar sebagai kemampuan perusahaan untuk membayar kewajiban di masa yang akan datang dan adanya risiko bisnis yang rendah, akan direspon secara positif oleh pasar (Brigham dan Houston, 1999). 


\section{Konsep Dasar}

Beikut ini adalah konsep dar dari penelitian ini

\section{Nilai Perusahaan}

Tujuan utama perusahaan adalah untuk meningkatkan nilai perusahaan melalui peningkatan kemakmuran pemilik atau para pemegang saham. Nilai perusahaan pada dasarnya diukur dari beberapa aspek salah satunya adalah harga pasar saham 101perusahaan, karena harga pasar saham perusahaan mencerminkan penilaian investor atas keseluruhan ekuitas yang dimiliki (Permanasari, 2010).

\section{Stuktur Aset}

Bambang Riyanto (2008:22) menyatakan bahwa: "Struktur aktiva atau struktur kekayaan adalah perimbangan atau perbandingan baik dalam artian absolut maupun dalam artian relatif antara aktiva lancar dengan aktiva tetap. Yang dimaksud dengan artian absolut adalah perbandingan dalam bentuk nominal, sedangkan yang dimaksud dengan artian relatif adalah perbandingan dalam bentuk persentase.

Penelitian oleh Setiadharma (2017) yang meniliti tentang Pengaruh stuktur asset nilai perusahaan pada perusahaan firma property dan real estate yang terdaftar di Bursa Efek Indonesia periode 2010-2014. Menujukan bahwa struktur aset berpengaruh terhadap nilai perusahaan.

\section{H1: Struktur aset berpengaruh terhadap nilai perusahaan}

\section{Ukuran Perusahaan}

Menurut Husnan (2007:45) Ukuran perusahaan secara umum dapat diartikan sebagai suatu skala yang mengklasifikasikan besar atau kecil nya suatu perusahaan dengan berbagai cara antara lain dinyatakan dalam total aset, total penjualan, nilai pasar saham, dan lain-lain. Dilihat dari sisi kemampuan memperoleh dana untuk ekspanasi bisnis, perusahaan besar mempunyai akses yang besar ke sumber-sumber dana baik ke pasar modal maupun perbankan untuk membiayai investasinya dalam rangka meningkatkan labanya (Harahap, 2009).

Penelitian oleh Putu Ayu et all (2018) yang meneliti tentang Ukuran Perusahaan pada Nilai Perusahaan pada perusahaan consumer goods yang 
terdaftar di BEI periode 2011-2015 menujukan bahwa ukuran perusahaan berpengaruh positif pada nilai perusahaan.

\section{H2: ukuran perusahaan berpengaruh terhadap nilai perusahaan}

\section{Profitabilitas}

Menurut Kasmir (2012) profitabilitas merupakan suatu ukuran tentang efektivitas manajemen dalam mengelola investasinya.Selain itu, hasil pengembalian investasi menunjukkan produktivitas dari seluruh dana perusahaan, baik modal pinjaman maupun modal sendiri. Semakin kecil rasio ini, maka semakin kurang baik, demikian pula sebaliknya. Artinya, rasio ini digunakan untuk mengukur efektivitas dari keseluruhan operasional perusahaan.

Eka indriyani (2017) yang meniliti tentang Profitabilitas Terhadap Nilai Perusahaan pada perusahaan manufaktur sektor makanan dan minuman di Bursa Efek Indonesia periode tahun 2011 sampai dengan 2015. Penelitian ini menggunakan metode analisis regresi linier berganda. Hasil penelitian tersebut menunjukan bahwa. Profitabilitas berpengaruh positif terhadap nilai perusahaan. Berdasarkan teori dan dukungan dari hasil penelitian tersebut, maka hipotesis yang diajukan dalam penelitian ini adalah

\section{H3: Profitabilitas berpengaruh terhadap nilai perusahaan.}

\section{Kerangka pemikiran}

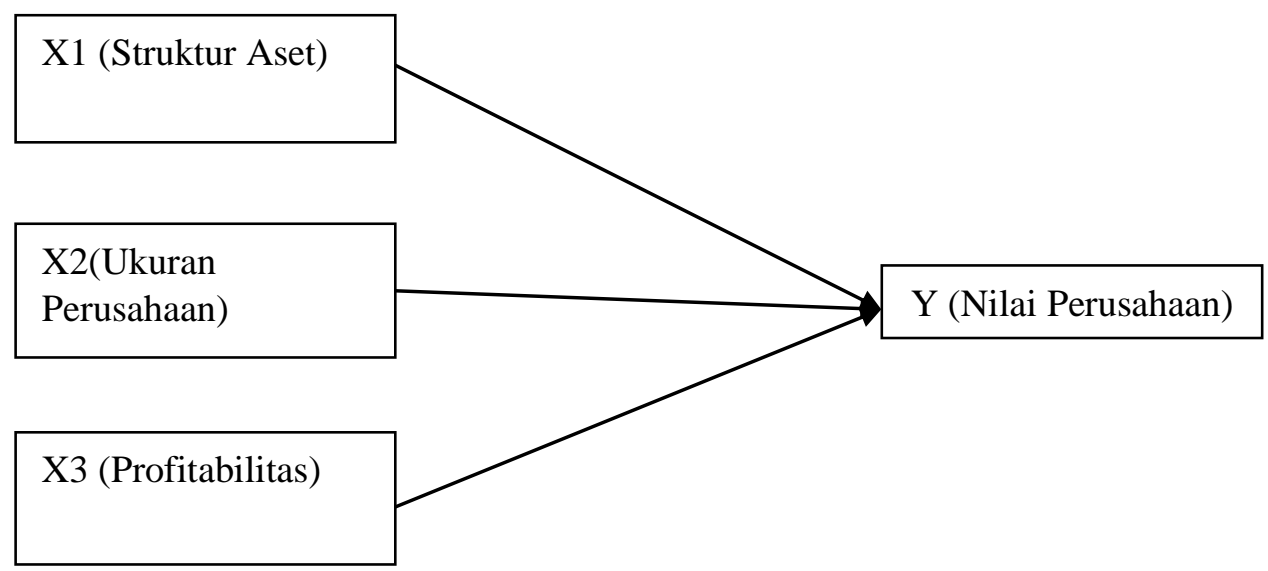

Gambar 1. Kerangka Berpikir 


\section{METODE PENELITIAN}

Metode analIsis data yang dilakukan dalam penelitian ini yaitu analisis statistic descriptive. Menurut Sekaran dan Boguie (2009), Descriptive digunakan untuk memperoleh gambaran yang dapat menjelaskan karakteristik dari variabelvariabel tanpa adanya perbandingan dengan variabel lainnya. Pengambilan sampel dalam penelitian ini menggunakan metode purposive sampling yang dimana populasi yang digunakan sebagai sampel peneelitian ini harus sesuai kriteria sampel yang telah dikehendaki peneliti yang sudah dipertimbangkan. Populasi yang digunakan peneliann ini yaitu perusahaan sector real estate, properti, dan konstruksi bangunan yang terdaftar di Bursa Efek Indonesi (BEI) periode 20152018.

Tabel 1. Pemilihan Sampel Hasil Purposive Sampling Berdasarkan Kriteria Pada Perusahaan Sector Real Estate , Properti dan Kontruksi Bangunan Periode 2015-2018

\begin{tabular}{rlc}
\hline No & \multicolumn{1}{c}{ Keterangan } & Jumlah \\
\hline 1 & $\begin{array}{l}\text { Perusahaan Sub Sector Real Estate, Properti, dan Konstruksi } \\
\text { Bangunan yang terdaftar secara berturut-turut di Bursa Efek }\end{array}$ & 72 \\
& $\begin{array}{l}\text { Indonesia (BEI) dan mempublikasikan laporan keuangannya dari } \\
\text { tahun 2015 - 2018. }\end{array}$ \\
2 & $\begin{array}{l}\text { Perusahaan Sub Sector Real Estate, Properti, dan Konstruksi } \\
\text { Bangunan yang mengalami suspend selama periode penelitian, }\end{array}$ \\
3 & $\begin{array}{l}\text { Perusahaan Sub Sector Real Estate, Properti, dan Konstruksi } \\
\text { Bangunan yang mengalami kerugian selama periode penelitian }\end{array}$ \\
5 & Jumlah perusahaan yang menjadi sampel \\
6 & Total Observasi (4 tahun) = 40 x 4 tahun \\
7 & Data Outlier & 40 \\
8 & Jumla data (N) & 160 \\
\end{tabular}


Tabel 2. Operasionalisasi Varibel Penelitian

\begin{tabular}{|c|c|c|c|}
\hline No & Variabel & Indikator & Skala \\
\hline 1. & Struktur Aset & $\begin{array}{l}\text { Asset Structure }=\frac{\text { Fixed Asset }}{\text { Total } \text { Assets }} \times 100 \% \\
\text { (Brigham dan Houton ,2006) }\end{array}$ & Rasio \\
\hline 2. & \begin{tabular}{|l|} 
Ukuran \\
Perusahaan
\end{tabular} & $\begin{array}{l}\text { Firm Size }=(\text { Ln) Total Aset } \\
\text { Ln : Logaritma Natural } \\
\text { Titman, S. dan R, Wessels, } 1988\end{array}$ & Rasio \\
\hline 3. & \begin{tabular}{|l|} 
Profitabilitas \\
\end{tabular} & $\begin{array}{l}\text { ROA }=\frac{\text { Laba bersih setlah pajak }}{\text { Total Aset }} \times 100 \% \\
\text { Hanafi dan Halim, } 2003\end{array}$ & Rasio \\
\hline 4. & \begin{tabular}{|l} 
Nilai \\
Perusahaan
\end{tabular} & $\begin{array}{l}\text { Q }=\frac{(E M V+D)}{(E B V+D)} \times 100 \% \\
\text { Q } \quad \text { : Nilai Perusahaan } \\
\text { EMV } \quad \text { : Nilai Pasar Ekuitas } \\
\text { EBV } \quad \text { : Nilai Buku dari Total Aktiva } \\
\text { D } \quad \text { : Nilai Buku dari total hutang } \\
\\
\text {.Weston dan Copeland, } 2001\end{array}$ & Rasio \\
\hline
\end{tabular}




\section{HASIL PENELITIAN}

\section{Analisis Statistik Deskriptif}

Tabel 3. Analisa Deskriptive

Descriptive Statistics

\begin{tabular}{|l|r|r|r|r|r|}
\hline & N & Minimum & Maximum & Mean & Std. Deviation \\
\hline Struktur Aset (X1) & 89 &, 34 & 21,03 & 6,6496 & 5,20642 \\
Ukuran Perusahaan (X2) & 89 & 2794,12 & 3245,45 & 2995,9713 & 103,32454 \\
Profitabilitas (X3) & 89 &, 02 & 11,76 & 4,5521 & 2,90136 \\
Nilai Perusahaan (Y) & 89 & 55,28 & 186,47 & 109,5265 & 32,48585 \\
Valid N (listwise) & 89 & & & & \\
\hline
\end{tabular}

1. Struktur Aset

Variabel Struktur Aset menunjukkan nilai minimum sebesar 0.34 yang terjadi pada Mega Manunggal Property Tbk (MMLP) tahun 2016 dan nilai maksimum sebesar 21,03 yang terjadi pada Kawasan Industri Jababeka Tbk (KIJA) tahun 2017. Sedangkan nilai mean sebesar 6,6496 dan nilai standar deviasi sebesar 5,20642.

2. Ukuran Perusahaan

Variabel Ukuran Perusahaan menunjukkan nilai minimum sebesar 2794,12 yang terjadi pada Megapolitan Developments Tbk (EMDE) tahun 2016 dan nilai maksimum sebesar 3245,45 yang terjadi pada Waskita Karya (Persero) Tbk (WSKT) tahun 2018. Sedangkan nilai mean sebesar 2995,9713 dan nilai standar deviasi sebesar 103,32454.

3. Profitabilitas

Variabel Profitabilitas menunjukkan nilai minimum sebesar 0,02 yang terjadi pada Gading Development Tbk (GAMA) tahun 2017 dan nilai 
maksimum sebesar 11,76 yang terjadi pada Jaya Real Property Tbk (JRPT) tahun 2017. Sedangkan nilai mean sebesar 4,5521 dan nilai standar deviasi sebesar 2,90136.

4. Nilai Perusahaan

Variabel Pertumbuhan Penjualan menunjukkan nilai sebesar 55,28 yang terjadi pada Lippo Cikarang Tbk (LPCK) tahun 2017 dan nilai maksimum sebesar 186,47 yang terjadi pada Pakuwon Jati Tbk (PWON) tahun 2017. Sedangkan nilai mean sebesar 109,5265 dan nilai standar deviasi sebesar 32,48585 .

\section{Uji Asumsi Klasik}

Dalam uji asumsi klasik yang digunakan dalam penelitian ini berguna untuk mengetahui ada tidaknya normalitas residual, multikolinieritas, autokolerasi, dan heteroskedastisitas. Yang dimana syart-syaratnya harus terpenuhi supaya model tersebut menjadi valid sebagai alat penduga.

a. Uji Normalitas Residual

Untuk model regresi yang baik memiliki nilai residual yang terdistribusi normal atau mendekati normal.

Dilihat dari nilai signifikasi maka nilai sig nya harus $>0,05$. Dari nilai signifikasi itulah bisa dinyatakan terdistribusi normal.

Tabel 4. Uji normalitas (One-Sample Kolmogorov-Smirnov)

\begin{tabular}{ccccc}
\hline \hline Variabel & $\mathbf{N}$ & $\begin{array}{c}\text { Asymp. Sig (2- } \\
\text { tailed) }\end{array}$ & Standar & Keterangan \\
\hline \hline $\begin{array}{c}\text { Unstandardized } \\
\text { Residual }\end{array}$ & 89 & 0,200 & $>0,05$ & Normal \\
\hline
\end{tabular}

Sumber: Lampiran

Dari hasil tabel 4 diatas menujukan bahwa nilai signifikasi (Asymp. Sig 2tailed) sebesar 0,200, yang berarti nilai signifikasinya diatas atau lebih besar dair standar deviasi >0,05 maka uji nilai residual terdistibusi secara normal. 
b. Uji Autokorelasi

Untuk model regresi yang baik maka tidak terjadi autokorelasi dalam penelitian ini menggunakan uji Durbin Watson (Dw-test). Keputusan untuk hasil Durbin Watson (Dw-test) yaitu:

1) DU < DW < 4-DU maka Ho diterima, artinya tidak terjadi autokolerasi.

2) DW < DL atau DW > 4-DL maka Ho ditolak, artinya terjadi autokolerasi.

3) DL $<$ DW $<$ DU atau 4-DU $<$ DW $<4-D L$, artinya tidak ada kepastian atau kesimpulan yang pasti.

Tabel 5. Uji Autokorelas Durbin Watson

\begin{tabular}{cccccc}
\hline \hline $\begin{array}{c}\text { Dw- } \\
\text { test }\end{array}$ & Du & dL & 4-Du & 4-dL & Keterangan \\
\hline \hline $\mathbf{1 , 8 9 6}$ & 1,725 & 1,583 & 2,275 & 2,417 & Tidak terjadi autokorelasi \\
\hline
\end{tabular}

Sumber: lampiran

Hasil uji Durbin-Watson menunjukkan nilai DW sebsesar 1,896. Nilai ini dibandingkan dengan nilai dari tabel Durbin-Watson(k,n) dengan k menunjukkan jumlah variabel independen yaitu 3, dan $\mathrm{n}$ adalah jumlah sampel yang berjumlah 89 data. Hasil analisis menunjukkan DU < DW < 4DU atau 1,725 $<1,896<2,275$ sehingga dapat disimpulkan model regresi terbebas dari autokorelasi dan layak digunakan.

c. Uji Multikoloneraritas

Tabel 6. Uji Multikolinieritas (VIF)

\begin{tabular}{|c|c|c|c|c|c|}
\hline Variabel & Tolerance & Standar & $\overline{\text { VIF }}$ & Standar & Keterangan \\
\hline $\begin{array}{l}\text { Struktur } \\
\text { Aset }\end{array}$ & 0.912 & $>0,1$ & 1.097 & $<10$ & $\begin{array}{c}\text { Bebas } \\
\text { Multikoloneraritas }\end{array}$ \\
\hline $\begin{array}{c}\text { Ukuran } \\
\text { Perusahaan }\end{array}$ & 0.934 & $>0,1$ & 1.071 & $<10$ & $\begin{array}{c}\text { Bebas } \\
\text { Multikoloneraritas }\end{array}$ \\
\hline Profitabilitas & 0.901 & $>0,1$ & 1.110 & $<10$ & $\begin{array}{c}\text { Bebas } \\
\text { Multikoloneraritas }\end{array}$ \\
\hline
\end{tabular}

Sumber: lampiran 
Dalam menguji Multikoloneraritas di penelitiaan ini menggunakan tolerance value dan variance inflation factor VIF. Denganmdemikian tabel 6 menunjukan bahwa nilai tolerace ke tiga variabel tersebut lebih besar dari 0,10 dan VIF kurang dari 10 , jadi dapat disimpulkan bagwa tidak terjadi multikolinieritas antar variabel bebas dan penelitian ini layak dilanjutkan.

d. Uji Heterokedastisitas

Tabel 8. Uji Heterokedastisitas (Spearman’ Rho)

\begin{tabular}{cccc}
\hline \hline Variabel & $\begin{array}{c}\text { Sig. (2- } \\
\text { tailed) }\end{array}$ & Standar & Keterangan \\
\hline \hline Struktur Aset & 0,872 & 0,05 & $\begin{array}{c}\text { Bebas } \\
\text { Multikoloneraritas }\end{array}$ \\
\hline $\begin{array}{c}\text { Ukuran } \\
\text { Perusahaan }\end{array}$ & 0,717 & 0,05 & $\begin{array}{c}\text { Bebas } \\
\text { Multikoloneraritas }\end{array}$ \\
\hline Profitabilitas & 0,881 & 0,05 & $\begin{array}{c}\text { Bebas } \\
\text { Multikoloneraritas }\end{array}$ \\
\hline
\end{tabular}

Sumber: lampiran

Tes heteroskedastistas dalam penelitian ini menggunakan uji tes spearmans' rho yang dimana mengorelasikan variabel independen denngan residualnya. Berdasarkan tabel diatas, menunjukan bahwa setiap variabelnya menujukan lebih besar dari $>0,05$, jadi dapat di simpulkan tidak ada masalah heteroskedastisitas.

\section{Uji Regresi linier Berganda}

a. Model Regresi

Tabel 9. Model Regresi

\begin{tabular}{ccc}
\hline \hline & Model & Keterangan \\
\hline \hline $\mathbf{1}$ & (Constant) & $-47,963$ \\
\hline & Struktur Aset & 1,485 \\
\hline & Ukuran perusahaan & 0,040 \\
\hline & Profitabilitas & 5,924
\end{tabular}

Sumber: lampiran 


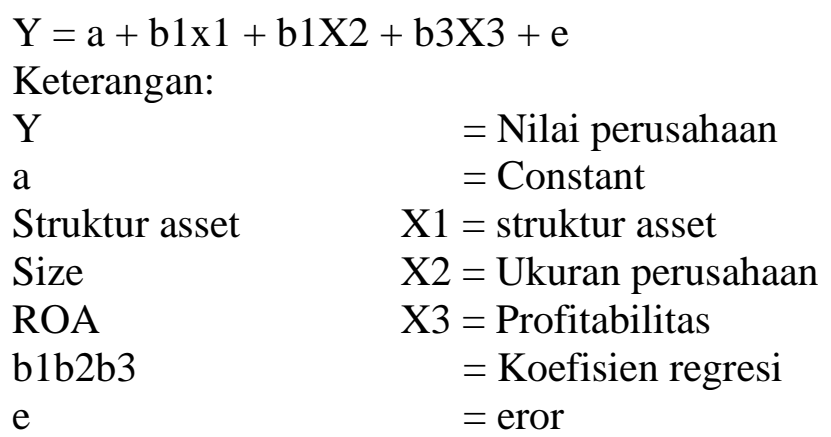

Maka model regresri di penelitian ini:

$\mathrm{Y}=-47,963 \alpha+1,485 \mathrm{X} 1+0,40 \mathrm{X} 2+5,924 \mathrm{X} 3+\varepsilon$

\section{Uji Kelayakan Model}

1) The Simultaneous Test (F Test)

Tes silmutan dari penelitian ini menggunakan uji F- Statistikk. Yang diambil dari uji Analisis varian menguji signifikansi beberapa variabel independen terhadap variabel dependen. Pengujian menggunakan tingkat signifikansi 0,05 . Kriteria pengujian jika $F$ hitung $>\mathrm{F}$ tabel dan nilai signifikansi <0,05 maka HI diterima dan Ho ditolak.

Tabel 10. Tes F-Statistik

\begin{tabular}{cccccc}
\hline \hline Model & $\begin{array}{c}\text { F } \\
\text { hitung }\end{array}$ & $\begin{array}{c}\text { F } \\
\text { tabel }\end{array}$ & Sig & Standar & Keterangan \\
& & & & & \\
\hline $\begin{array}{c}\text { Regresi } \\
\mathbf{1}\end{array}$ & 10.391 & 2.712 & 0.000 & $<0,05$ & $\begin{array}{l}\text { Secara simultan } \\
\text { Berpengaruh }\end{array}$ \\
\hline
\end{tabular}

Sumber: Lampiran

Dari tabel 10 menunjukan bahwa struktur aset, ukuran perusahaan dan profitabilitas secara silmutan mempengaruhi nilai perusahaan.

2) Tes Hipotesis ( $t$ Test)

Di penelitian ini uji $\mathrm{t}$ menggunakan tingkat signifikansi 0,05 dam nilai $\mathrm{t}$ hitung. Kriteria pengujian apabila $t$ hitung $>\mathrm{t}$ tabel dan nilai sig $<0,05$ maka variabel independen secara persial mempengaruhi variabel dependen.

Tabel 11.

Uji Hipotesis (Uji t)

\begin{tabular}{cccccc}
\hline \hline Hipotesa & $\begin{array}{c}\text { T } \\
\text { hitung }\end{array}$ & $\begin{array}{c}\text { T } \\
\text { tabel }\end{array}$ & Sig. & Standar & Keterangan
\end{tabular}




\begin{tabular}{llllll}
\hline \hline H1 & 2.450 & 1.998 & 0,016 & 0,05 & Diterima \\
\hline H2 & 1.334 & 1.998 & 0,186 & 0,05 & Ditolak \\
\hline H3 & 5.412 & 1.998 & 0,000 & 0,05 & Diterima
\end{tabular}

Sumber: Lampiran

Dari hasil tabel dapat disimpulkan bahwa struktur aset dan profitabilitas secara persial mempengaruh nilai perusahaan, sedangakan ukuran perusahaan tidak mempengaruhi nilai perusahaan

3) Uji koefisien Determinasi $\left(R^{2}\right)$

Tabel 12. Coefficient of determination $\left(R^{2}\right)$ Test

\begin{tabular}{cccccc}
\hline \hline $\mathbf{R}$ & $\begin{array}{c}\text { R Square } \\
\left(\mathbf{R}^{2}\right)\end{array}$ & $\begin{array}{c}\text { Adjuste } \\
\mathbf{d ~ R} \\
\text { Square }\end{array}$ & $\begin{array}{c}\text { Stdr. error of } \\
\text { the estimated }\end{array}$ & Keterangan & $\begin{array}{l}\text { Sum } \\
\text { ber: } \\
\text { Lam } \\
\text { pira } \\
\mathrm{n}\end{array}$ \\
\hline \hline $\mathbf{0 , 4 6 1}$ & 0,212 & 0,184 & 24,48861 & $\begin{array}{c}\text { Berpengaruh sebesar } \\
18.4 \%\end{array}$ & \\
& & & &
\end{tabular}

Dari hasil uji koefisien derteminasi yang ditunjukan pada tabel, dilihat besarnya nilai Adjusted $R$ Square adalah 0.184 atau sebesar 18.4\%. Hal ini berarti $18.4 \%$. dari nilai perusahaan, dapat dijelaskan oleh variabel-variabel struktur aset ukuran perusahaan. Sedangkan sisanya sebesar 81,6\% (100\%-18.4\%) dijelaskan oleh variabel-variabel yang lain selain variabel penjelas atau variabel independen diluar model penelitian ini.

\section{PEMBAHASAN}

Berdasarkan hasil ujin yang telah dilakukan dalam penelitian ini bahwa hipotesis pertama Struktur aset mempengaruhi nilai perusahaan. Penelitian ini sejalan dengan penelitian (Setiadharma, 2017) bahwa struktur set mempengaruhi secara langsung terhadap nili perusahaan. Dengan demikian hipotesis pertama dari penelitian ini diterima. Hasil penelitian ini menunjukkan bahwa komposisi aktiva tetap menentukan nilai perusahaan tertentu. Sebagian besar perusahaan dengan keuangan yang stabil memiliki nilai investasi yang tinggi dalam hal aktiva tetap. Ketika aktiva tetap tersebut dimanfaatkan secara optimal oleh staff yang 
kompeten, hal ini akan meningkatkan return perusahaan dan akhirnya berpengaruh pada pertumbuhan nilai perusahaan

Untuk hipotesis yang kedua Ukuran perusahaan berpengaruh negatif dan tidak signifikan terhadap nilai perusahaan. Hal ini berarti bahwa ukuran suatu perusahaan mempengaruhi nilai perusahaan namun tidak signifikan ditahun berikutnya. Hasil penelitian ini tidaknsejalan dengan hasil penelitian (Putu Ayu, 2018) yang menyatakan bahwa ukuran perusahaan berpengaruh positif terhadap nilai perusahaan. Namun pada penelitian ini dikatakannbahwa ukuran perusahaan tidak begitu berpengaruh terhadap nilainperusahaan dilihat dari hasil penelitiannya yang tidak signifikan. Ukuran perusahaan diukur dengan besarnya total asset yang dimiliki karena nilai total asset umumnya sangat besar dibandingkan variabel keuangan lainnya. Ukuran perusahaan bukan merupakan pertimbangan bagi para investor dalam berinvestasi. Ukuran perusahaan yang besar belum bisa menjamin nilai perusahaannya tinggi, karena perusahaaan besar mungkin belum berani melakukan investasi baru terkait dengan ekspansi, sebelum kewajiban - kewajibannya (hutang) sudah terlunasi. Hal ini juga menunjukkan besar kecilnya perusahaan tidak akan berpengaruh dengan besar kecilnya perusahaan.

Untuk hipotesis yang ketiga bahwa Profitabilitas memiliki pengaruh positif dan signifikan terhadap nilai perusahaan. Hal ini berarti keuntungan suatu perusahaan memiliki pengaruh yang sejalan terhadap nilai perusahaan. Hasil penelitian ini sejalan dengan hasil penelitian (Eka indriyani, Mardiyati, Ahmad, \& Abrar 2017) yang menyatakan bahwa profitabilitas berpengaruh positif terhadap nilai perusahaan. Pada dasarnya profitabilitas menunjukkan kemampuan perusahaan memperoleh laba bersih dari penjualan bersih nya dan juga dapat mengukur kemampuan manajemen perusahaan dalam menjalankan kegiatan operasionalnya dengan meminimalkan beban perusahaan dan memaksimalkan laba perusahaan. Dan hal ini lah yang dapat meningkatkan nilai perusahaan sehingga investor juga lebih tertarik untuk menanam saham pada perusahaan tersebut. 


\section{KESIMPULAN DAN SARAN}

Berdasarkan penjelasan diatas maka dapat disimpulkan bahwa:

1. Struktur Aset berpengaruh terhadap nilai perusahaan paba perushaan sector real estate, properti, dan konstruksi bangunan yang terdftar di Bursa Efek Indonesi (BEI) tahun 2015-2018.

2. Ukuran Perusahaan (Size) tidak berpengaruh terhadap nilai perusahaan paba perushaan sector real estate, properti, dan konstruksi bangunan yang terdftar di Bursa Efek Indonesi (BEI) tahun 2015-2018. Hal ini dikarenakan investor membeli saham sebuah perusahaan tidak hanya ditinjau dari seberapa besar a ktiva perusahaan namun juga dari sisi laporan keuangan.

3. Profitabilitas (ROA) berpengaruh positif dan signifikan terhadap nilai perusahaan sector real estate, properti, dan konstruksi bangunan yang terdftar di Bursa Efek Indonesi (BEI) tahun 2015-2018. Hal ini berarti keuntungan suatu perusahaan memiliki pengaruh yang sejalan terhadap nilai perusahaan.

4. Dari hasil yang telah di teliti dalam penelitian ini dengan pengukuran variabel struktur aset, ukuran perusahaan dan profitabilitas terhadap nilai perusahaan. Maka didapatkan bahwa perusahaan harus memperhatikan ukuran perusahaan atas dimensi struktur aktinyanya dan untuk perusahaan juga harus tetap mempertahanka factor-faktor lainnya yang mempengaruhi perusahan. Supaya segala aktivitas yang dilakukan perusahaan bisa berjalan dengan lancar dan mencapai tujuan yang telah ditetapkan.

Untuk kelemahan atau kekurangan di penelitian ini, peneliti hanya menggunakan tiga variabel saja yaitu struktur aset, ukuran perusahaan dan profitabilitan. Disarankan untuk penelitian selanjutnya agar menambah varibelnya dan menambah periode nya supaya hasil yang telah diteliti bisa lebih maksimal. Selain itu penelitian ini hanya dilakukan di peruhaan sub sector plantation tahun 2014 - 2017 saja. Penelitiselanjutnya dianjurkan supaya bisa meneliti lebih banyak di sub sektor lainnya yang terdaftar di Bursa Efek Indonesia. 


\section{DAFTAR PUSTAKA}

Armandi, I. W. 2016. Pengaruh Profitabilitas, Leverage, dan Ukuran Perusahaan pada Nilai Perusahaan Melalui Pengungkapan Tanggung Jawab Sosial (Vol.17). E-Jurnal Akuntansi Universitas Udayana.

Andini, Ni Wayan Lady, dan Ni Gusti Putu Wiranawati. 2014. Pengaruh Cash Flow Pada Kinerja Keuangan Dan Implikasinya Pada Nilai Perusahaan Manufaktur Di Bursa Efek Indonesia. E-Jurnal Akuntasi Universitas Udayana, 7(1); h: 107-121

Brealey, \& Myers. 2008. Dasar-Dasar Manajemen Keuangan Perusahaan Alih bahasa: Bob Sabran MM). Buku 2. Edisi ke-5. Jakarta : Erlangga,.

Dewi, A, S, M, \& Wirajaya, A. 2013. Pengaruh Struktur Modal, Protabilitas, dan Ukuran Perusahaan Pada Nilai Perusahaan, .358-372.

Delcoure N. 2006. The Determinants of Capital Structure in Transition Economies. Internal Review of Economic and Finance.

Harapan, Sofyan Syafri, 2009. Analisis Kritis Atas Laporan Keuangan. Jakarta: Raja Grafindo Persad

Husnan dan Pudjiastuti. 2012. Dasar-Dasar Manajemen Keuangan (6thed) Yogyakarta: UPP STIM YKPN

Jogianto. 2010. Metodologi Penilitian Bisnis. Edisi Pertama, BPFE. Yogyakarta.

Kasmir. 2012. Analisis Laporan Keuangan. Jakarta: PT Raja Geafindopersada.

Mandalika, A. 2016. Pengaruh struktur aktiva, struktur Modal, dan Pertumbuhan Penjualan Terhadap Nilai Perusahaan (Studi pada sector Otomotif) (Vol. 16). Berkala Ilmiah Efisiensi.

Nyamasege D, Okibo WBA, Nyang'au AS, Sang'ania PO, Omosa H, et al. 2014 Jurnal Penelitian Keuangan dan Akuntansi 5:205-212.

Titman, S., \& R, Wessels 1988. The Determinants of Capital Structure Choise. He Journal of Finance., Vol. 43. March No 1.

Pratama I Gede Gora Wira. 2016. Pengaruh Struktur Modal dan Protabilitas Terhadap Nilai Perusahaan Dengan Kepemilikan Majerial sebagai Pemoderasi. E-Jurnal Akuntansi Universitas Udayana, 15(3); h:1796-1825.

Sekaran, Uma dan Roger Bougie. 2009. Research Methods for Business: A Skill Buildong Approach 5th ed. United Kingdom: John Wiley and Sons.

Wahidahwati. 2002. Pengaruh Kepemilikan Manajerial Dan Kepemilikan Institusional pada Kebiijakan Hutang Perusahaan: Sebuah Perspektif Theory Agency, Jurnal Riset Akuntansi Indonesia, Vol. 5, No.1, Januari: Hal $1-16$. 